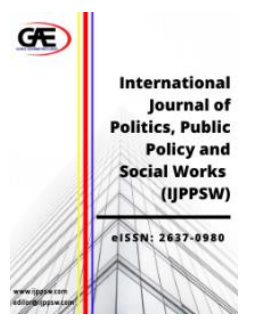

\author{
INTERNATIONAL JOURNAL OF \\ POLITICS, PUBLICS POLICY \\ AND SOCIAL WORKS \\ (IJPPSW) \\ www.ijppsw.com
}

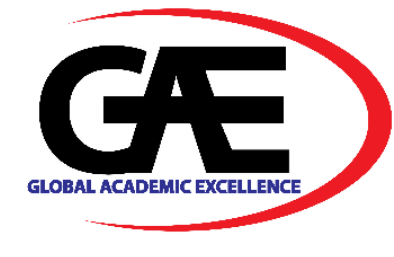

\title{
THE ROLE OF POLITICAL SOCIALIZATION ON FACEBOOK AMONG MALAYSIAN CHINESE
}

\author{
Edwin Michael ${ }^{1 *}$, Chin Yee Mun ${ }^{2}$ \\ 1 Department of Journalism, Universiti Tunku Abdul Rahman, Kampar Campus, Malaysia \\ Email: edwinm@utar.edu.my \\ 2 Department of General Studies, Universiti Tunku Abdul Rahman, Sungai Long Campus, Malaysia \\ Email: chinym@utar.edu.my \\ * Corresponding Author
}

\section{Article Info:}

Article history:

Received date: 14.04 .2021

Revised date: 15.04 .2021

Accepted date: 30.04 .2021

Published date: 15.06 .2021

\section{To cite this document:}

Michael, E., \& Chin, Y. M. (2021). The Role of Political Socialization on Facebook among Malaysian Chinese. International Journal of Politics, Publics Policy and Social Works, 3 (9), 01-08.

DOI: $10.35631 /$ IJPPSW.39001.

This work is licensed under $\underline{\text { C B BY 4.0 }}$

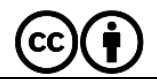

\begin{abstract}
:
The Barisan Nasional (BN), Malaysia's dominant coalition party that has ruled since 1957, lost the 14th general election. Various analyses were conducted, and many discussions centred on Chinese voters who had switched to opposition, Pakatan Harapan, and rejected BN entirely. This situation raises an interesting discussion about what prompted Chinese voters to make drastic changes in this ethnic-based country's politics. This study, therefore, focuses on whether political socialization in social media will build a political opportunity for Malaysian Chinese. In investigating how social media propaganda can provide Malaysian Chinese a political viewpoint, these studies argue that the internet and social media have led to unparalleled complexity in Malaysia's political socialization process. A bottom-up, constructivist approach is used to decide how social media played their position as Malaysian political socializers.
\end{abstract}

Keywords:

Political Socialization, Facebook, Malaysian Chinese

\section{Introduction}

According to the Department of Statics of Malaysia (2019), it was projected at 32.63 million for the third quarter of 2019, up 0.6 percent compared with the third quarter of 2018. (32.43 million). With 69.3 percent, ethnic Bumiputera reported the highest percentage, followed by 


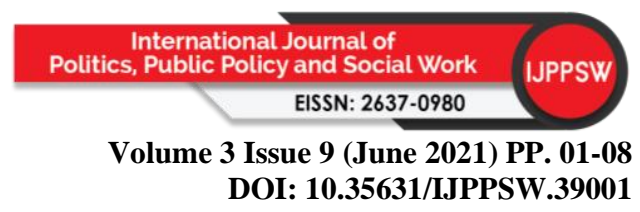

Chinese (22.8 percent), Indians (6.9 percent) and others (1.0 percent). This ethnic-based politics is something that deserves attention in the process of understanding nation-building because of the multi-racial and plural demographic structure of the people (Shamsul, 1997). It is in this sense that the study aims to examine Malaysian Chinese roles by using the social network site such as Facebook to become inspired to engage in a political socialization process. This study will explore online media political socialization mechanisms in a culture that dominates political information in conventional media and, in turn, forces people to look for political information in traditional media. and, in turn, compels citizens to seek alternative news sources online. Wong, Ezhar and Annette (2013) found that higher levels of political participation among Malaysian voters were positively correlated with online media use. Link between social media with political advocacy have been demonstrated by the usage and visibility of social networking sites, political blogs, political online videos, party websites, and political advertising on mobile phones.

\section{Literature Review}

\section{Social Media and Youth}

According to Pandian (2014), many young voters under the age of 39 voted for the first time in the 13th general election, giving victory to opposition candidates, particularly in urban parliamentary seats. This voter group is also described as having a high level of technological knowledge and relying solely on information obtained from the internet. These young voters are undecided voters with no fixed political ideology and Azhar (2012) claims that this group votes very carefully, considering the country's future. Because of this, this group is completely reliant on information obtained via the internet and social media (Chang \& Jen Sern. 2016).

Social media has a constructive role to play for the society. It is the fact that in most of the eras, social media were being given free and fair chances to explore the issues of society more openly than it is being given now (Rizuan et al, 2012). Around 86 percent of Malaysians were active social media users as of January 2021. This was a 24 percent increase from 2016, when social media users accounted for approximately 62 percent of Malaysia's total population. Facebook was the most popular social media platform there, out of all the ones available.

Facebook, Instagram, Facebook Messenger, and LinkedIn were the most popular social media platforms among Malaysians in 2020. According to Jamilah Ahmad (2015), the most active users of social media in Malaysia are those aged 13 to 34. This group focuses on social media sites such as Facebook, Twitter, and Instagram, which revolve around their daily lives. This assertion is backed up by Ismail (2014), who claims that social media users among these youth use it for communication, socialization, information gathering, and entertainment.

\section{Political Socialization and Social Media as a Political Tool}

Hess and Torney (1967) classified political socialization as a process of social learning and socialization refers to the process by which the beliefs, attitudes, and other conduct of a junior or new member of a community or institution is taught. Hyman (1959) proposed his own concept of political socialization, which naturally concerns learning; in particular, his learning of the social trends which correspond to his social positions as mediated through diverse social agencies. 


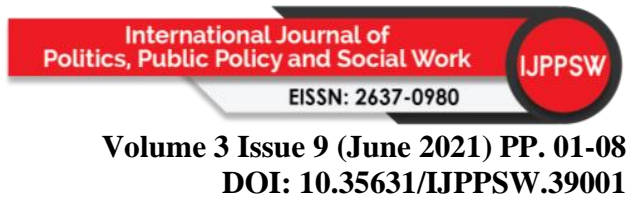

Langton (1969) defines politics as a mechanism mediated by various societal agencies, in which an individual acquires political significance in his attitudes and behaviour. The environmental categories of these organizations include family, peer group, education, adult and mass media organisations. Political socialization function at the level of the person and of the group, as Dawson and Prewitt (1969) have noted. It is better described at group level as cultural diffusion and political socialization explores the individual's political interactions. Gimple, Lay and Schluknecht, 2003, noted in the sense of political science that political socialization is the mechanism by which new generations are introduced into political culture, acquire the skills, values and behaviours that enable the political system to be supported.

In comparison with these definitions, it is clear that the majority of political socialization definitions have four components: (1), political socialization is a study process by which (2) the person (3) learns political attitudes and actions from one generation to the next, (4) is influenced by actors of political socialization. Although often there are minor variations in wording, both individual (learning) as well as group (cultural transmission) levels relate to the same unidirectional method of obtaining knowledge about the political system (Dawson \& Prewitt, 1969).

\section{Research Methodology}

Digital Ethnography explains the ethnographic study process and methodology in a digital space (Murthy, 2008; 2011). Creswell describes ethnography as "a research strategy that the researcher studies through observational data and interviews in an intact cultural group in a natural environment over a lengthy time. For this study MCA's leadership, Nicole Wong's discussion posts were investigated on the Nicole Wong Facebook page from the span of 16 days $(02 / 11 / 2019$ to $18 / 11 / 2019)$. Due to the material and the large number of participants of the Tanjung Piai elections, the Nicole Wong Facebook page was selected. The objective was to obtain a sample of at least five discussion papers relating to the Tanjung Piai by-election and to review Malaysian social interaction on Facebook with at least five answers each.

\section{Research Findings}

There are 50 by-election related posting published by the MCA Youth Leader. Of these, 5 randomly-selected posts were accepted for analysis, cumulatively attracting 2,232 comments.

\begin{tabular}{|l|l|c|c|}
\hline Date & Topic & $\begin{array}{l}\text { \# of likes } \\
\text { to the } \\
\text { Topic }\end{array}$ & $\begin{array}{l}\text { Total \# } \\
\text { Participants } \\
\text { in } \\
\text { Comment }\end{array}$ \\
\hline $\mathbf{0 2 / 1 1 / 2 0 1 9}$ & $\begin{array}{l}\text { Kita Pilih No.2 Wee Jeck Seng \#TgPiai } \\
\text { \#BNPilihanKu }\end{array}$ & 2263 & 177 \\
\hline $\mathbf{0 4 / 1 1 / 2 0 1 9}$ & $\begin{array}{l}\text { Jom kita berganding bahu dan \#tawanbalik Tanjung } \\
\text { Piai bersama sama! Undi Calon No.2 Wee Jeck } \\
\text { Seng pada 16.11.2019. Jgn lupa ya! \#JomTukar }\end{array}$ & 3016 & 263 \\
\hline
\end{tabular}




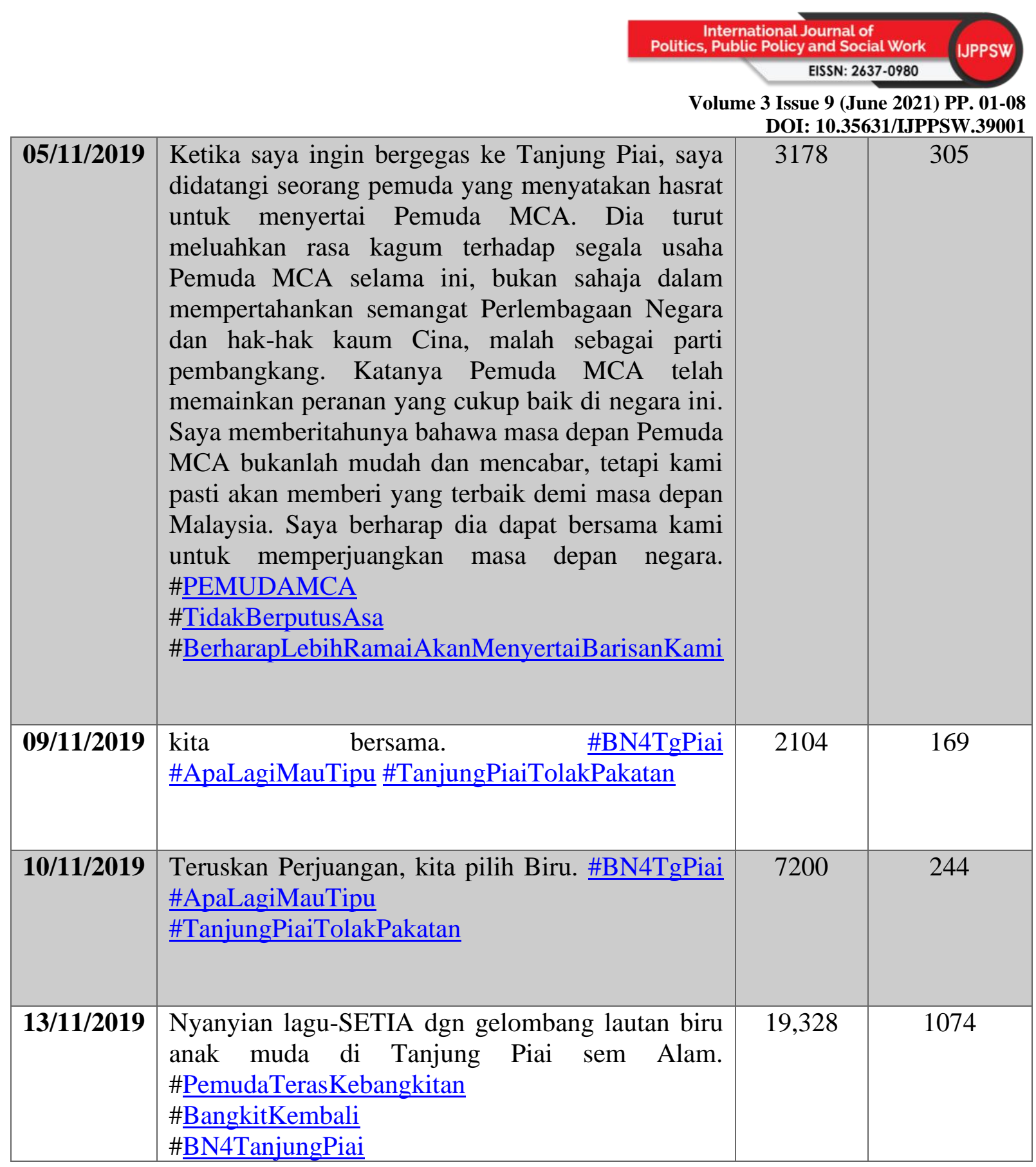

Figure 1: Five Randomly Chosen Post from Nicole Wong Facebook Page

A number of members participated in the discussions on the Nicole Wong Facebook page, including Malaysia and the Indians. 2.232 comments have been shared from five subjects to examine the way that participants use top-down and bottom-up methods in the Nicole Wong Facebook page. Based on the previous literature, coding began in a deductive manner with the three categories: knowledge, emotions, and connection with the online community (Oh, Kwon et al., 2010; Tampere et al., 2016). 
Volume 3 Issue 9 (June 2021) PP. 01-08

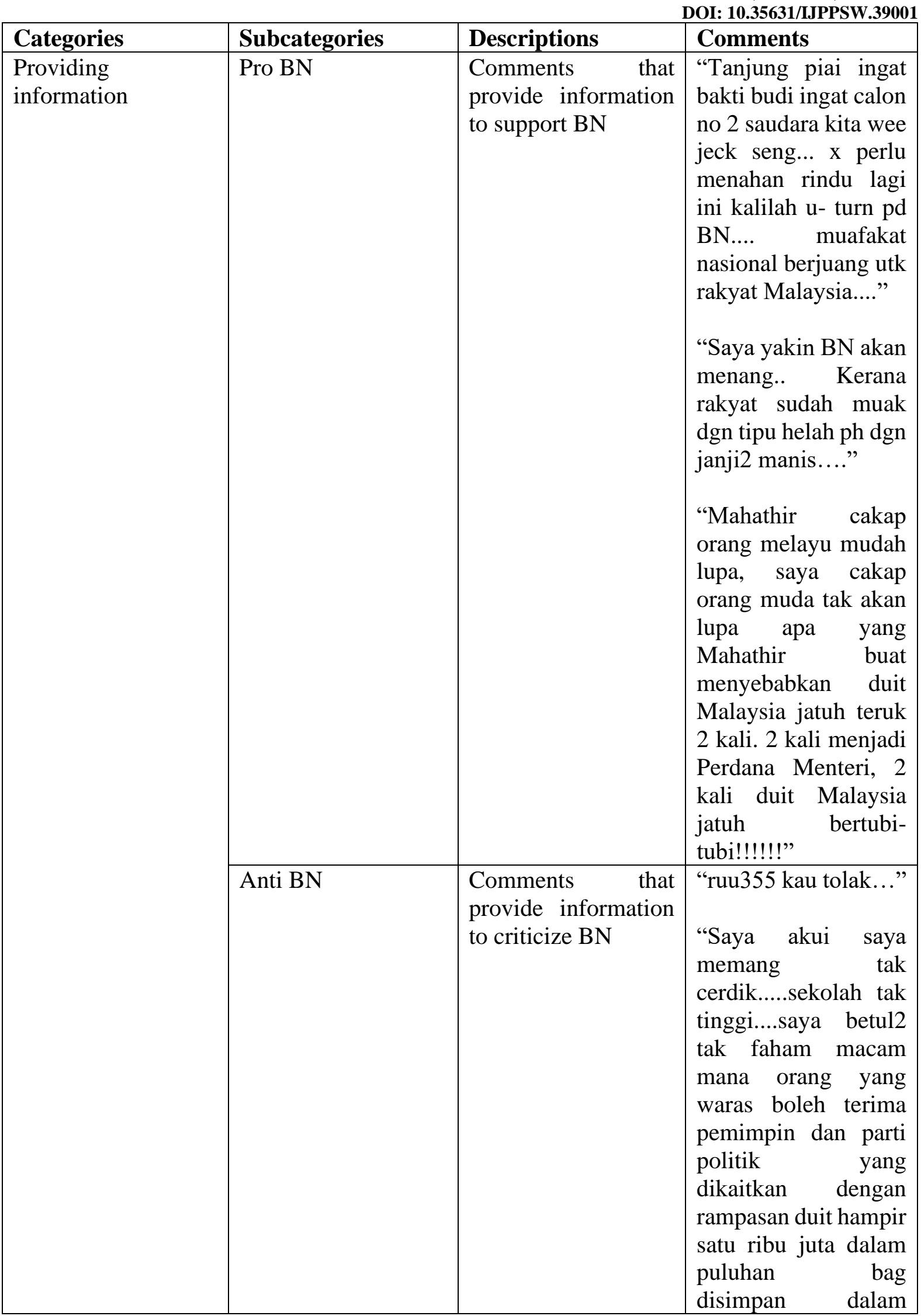




\begin{tabular}{|c|c|c|c|}
\hline & & \multicolumn{2}{|c|}{$\begin{array}{l}\text { International Journal of } \\
\text { Politics, Public Policy and Social Work }\end{array}$} \\
\hline & & \multirow{2}{*}{\multicolumn{2}{|c|}{$\begin{array}{r}\text { Volume } 3 \text { Issue } 9 \text { (June 2021) PP. 01-08 } \\
\text { DOI: 10.35631/IJPPSW.3900 }\end{array}$}} \\
\hline & & & \\
\hline & & & 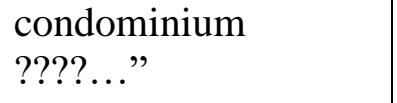 \\
\hline $\begin{array}{l}\text { Forging connection } \\
\text { with the online } \\
\text { community }\end{array}$ & Call to action & $\begin{array}{l}\text { Comments that } \\
\text { encourage the } \\
\text { followers to support } \\
\text { BN }\end{array}$ & $\begin{array}{l}\text { "Terbaik tanjung } \\
\text { piai.teruskan } \\
\text { menyokong BN..." }\end{array}$ \\
\hline & & & $\begin{array}{l}\text { "Tahniah MCA } \\
\text { kerana menujukan } \\
\text { sikap positif, semoga } \\
\text { kemakmuran di } \\
\text { negara kita kembali } \\
\text { gah di zaman era } \\
\text { BN..." }\end{array}$ \\
\hline Others & Irrelevant content & $\begin{array}{l}\text { Comments that are } \\
\text { unrelated to the } \\
\text { Tanjung Piai by- } \\
\text { election. }\end{array}$ & $\begin{array}{l}\text { "lawa org nya..." } \\
\text { "Ni please find } \\
\text { attached the } \\
\text { invoice..." }\end{array}$ \\
\hline
\end{tabular}

Figure 2: Categories and Subcategories of Comments (Adapted from Pal, A. Et Al., 2017)

\section{Discussion}

Overall, Pro BN commented on posts made on the Facebook page of Nicole Wong. All 50 posts on the Facebook page have been written in Malay and not one in English or Mandarin. And the commentators are mostly from different ethnic groups as all the articles are written in Malay. The \#takebackourcountry hash tag was one of the most widely used hash tags in the comment section. Instead, the anti-BN comments are based on attempts by the MCA to oppose the RUU355 law and on those who support the \#VMF or Vote Muslim First movement focused on the candidate from BERJASA. While it was very aggressive with the Vote Muslim First (\#VMF) movement, Gerakan Pengundi Sedar (GPS) overall did not impact the 'Muafakat Nasional' propaganda. It was very aggressive. Comments like 'Terbaik Nasional Muafakat' and 'Undi Nasional Muafakat' belong to the most popular comments found in nearly all posts on this Facebook page. Knowledge acceptance is based on top-down methods. The best example is based on the reporting of the MCA and PAS policy partnership on 13/11/2019, which earned 19,036 likes and 1,074 observations. This sends a strong message that the political position of the commentators on this Facebook page is already driven by top-down facts and misinformation.

According to Abyyzar (2017), political participation is one type of active community involvement in political decision-making. In the context of the political socialization process in social media, it is necessary to recognize that there is autonomous and voluntary participation, as well as mobilized participation that is essentially intangible. Traditional steps in political participation, according to Dahl (1989, in Putnam, 2000), are usually demonstrated by votes, campaigns, and monetary donations, as seen from the foundation of democracy. Many studies, however, have found that this type of participation is declining, particularly among 


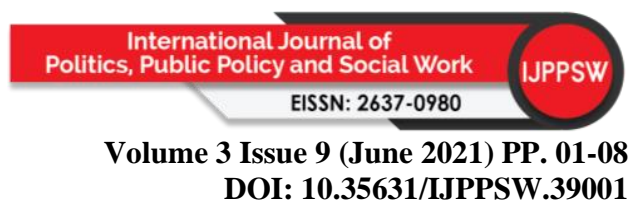

young voters (Zukin, Keeter, Adoline, Jenkins, \& Carpini, 2006). Political participation is currently carried out in a variety of ways, with young people finding it easier, more practical, flexible, and personal to respond to these socio-political issues. Because of the nature of social media, which tends to be semi-interpersonal and semi-mass, young people or adolescents prefer to express their political aspirations through it.

Malaysians are socialized politically through social media which have been an agent for shaping their political attitude. These selective comments demonstrate how a leader from a political party with an ethnic political ideology can pique the interest of people of various ethnicities on social media. This demonstrates that Malaysian Chinese social media users socializing on Nicole Wong's Facebook page will undoubtedly influence political views, resulting in an inclusive politics of how a Chinese political party leader is able to unite people of various races on her Facebook page. This inclusive politics is also thought to be one of the factors that helped the Barisan Nasional candidate from a Chinese-based party, MCA, win a large majority in the Tanjung Piai by-election. In other words, the socialization process in social media has the potential to create not only political socialization but also inclusive politics, regardless of ethnicity or language.

\section{Conclusion}

This top-down knowledge opens the way to an active dialogue on social media policy issues. Although this is basically a good step in the process of democratic participation involving the people but this process also does not basically reflect the participation of all Malaysians because the use of fake accounts to provoke an issue has also damaged this process of political socialization. However, this process of political socialization is no longer just mainstream but also develop a political self, a sense of personal identification within the political world in social media.

\section{Acknowledgements}

This research funded by Universiti Tunku Abdul Rahman Research Fund (IPSR/RMC/UTARRF/2019-C1/E01).

\section{References}

Abyyzar, A. (2017). Peran Media Sosial Dan Partisipa si Politik Remaja Dalam Konteks Komunikasi Politik Di Kabupaten Sumbawa. Jurnal Tambora, Vol 2 No 3.

Ahmad, J. (2015). Investigating Malaysian Youth's Social Media Usage, Competencies and Practice with regard to Crime Prevention: An Application of the Social Media Literacy Model.

Andersen, K. (2007). A New Engagement? Political Participation, Civic Life, and the Changing American Citizen. Perspectives on Politics, 5(2), 379-380. doi:10.1017/S1537592707071150

Azhar, N. A. (2012). Malaysian youth: Connected yet cautious. The Asia Foundation. San Francisco: Author. Retrieved from http://asiafoundation.org/2012/12/19/malaysianyouth-connected-yet-cautious/

Banton, M. (2011). A theory of social category, Sociology, vol. 45, 187-201.

Chin, Y.M., Chang, Y.F., Wu, M.C. (2015). Recent Chinese Malaysians' Political Decision: A Matter of Rational Choice. International Journal of Social Science and Humanity, Vol. 5 (6), 530-536. 


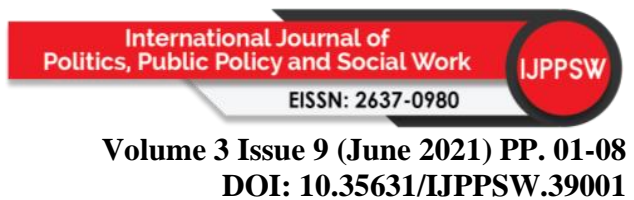

Cresswell, J.W. (2009). Research Design: Qualitative, quantitative and mixed methods approach. Thousand Oaks, CA: Sage Publication.

Dahl, R. A. (1989). Democracy and its critics. New Haven: Yale University Press

Dawson, R. E., \& Prewitt, K. S. (1969). Political socialization. An analytic study. Boston, MA: Little Brown.

Gimpel, J. G., Lay, C. J., \& Schuknecht, J. E. (2003). Cultivating democracy. Civic environments and political socialization in America. Washington, D.C, USA. Brookings Institution Press.

Hess, R. D., \& Torney, J. V. (1967). The development of political attitudes in children. Chicago, NJ: Aldine Press.

Hyman, H. H. (1959). Political socialization. Glencoe, NY: Free Press.

Ismail, N. (2014). Young people's use of new media through communities of practice. (PhD), Monash University, Australia.

Langton, K. P. (1969). Political socialization. New York, US: Oxford University Press.

Lars, W., Wong, J.W., Ezhar, T. \& Annette, A. (2013). Online Media and Political Participation: The Case of Malaysia, Mass Communication and Society, 16(4), $557-$ 585. DOI: $10.1080 / 15205436.2012 .73489$

Murthy, D. (2008). Digital Ethnography: An Examination of the Use of New Technologies for Social Research. Sociology, 42, 837-855.

Oh, O., Kwon, K. H. and Rao, H. R. 2010. "An Exploration of Social Media in Extreme Events: Rumor Theory and Twitter during the Haiti Earthquake 2010," in Proceedings of the International Conference on Information Systems, available at: http://aisel.aisnet.org/cgi/viewcontent.cgi?article=1223\&context=icis2010_submissio ns (accessed 12 March, 2016).

Pal, A., Chuan Y.K., Goh, D.H.L. (2017). "Analysis of Facebook Comments in Response to Counter Rumors" in Proceedings of the Pacific Asia Conference on Information Systems, available at: https://aisel.aisnet.org/cgi/viewcontent.cgi?article=1155\&context=pacis2017 (accessed 12 November, 2019).

Pandian, S. (2014). The importance of issues for youth in voter decision making: A case study among university students in Malaysia. International Journal of Social, Behavioral, Educational, Economic, Business and Industrial Engineering, 8(8), 2723-2727. Retrieved from http://waset.org/publications/9999572/the-importance-of-issues-forthe-youth-in-voter-decision-making-a-case-study-among-university-students-inmalaysia

Peng Kee, Chang \& Tham, Jen Sern. (2016). Media Usage Patterns among Chinese Voters: In Preparation for the 14th Malaysian General Election (GE14). Asian Social Science. 12. 251. 10.5539/ass.v12n12p251.

Putnam, R. D. (2000). Bowling alone: The collapse and revival of American community. New York: Simon \& Schuster.

Ridzuan, Abdul Rauf and Bolong, Jusang and Omar, Siti Zobidah and Osman, Mohd Nizam and Yusof, Rozman and Abdullah, Siti Faidul Maisarah (2012) Social media contribution towards ethnocentrism. Procedia - Social and Behavioral Sciences, 65. pp. 517-522. ISSN 1877-0428 https://doi.org/10.1016/j.sbspro.2012.11.158.

Zaller, J. (1992) The Nature and Origins of Mass Opinion. Cambridge: Cambridge University Press. 